\title{
PERBEDAAN EFEKTIVITAS MASASE DENGAN KOMPRES PANAS DINGIN TERHADAP PENGURANGAN NYERI KALA I PADA IBU BERSALIN DI PUSKESMAS JUMPANDANGBARU
}

\author{
Irnawati, Uliarta Marbun \\ STIKES Nani Hasanuddin Makassar \\ Irnawati731@yahoo.com/085331488880
}

\begin{abstract}
Labor pain can cause suffering to the mother and her health. This has a negative impact on the relationship between mother and baby. According to a study, many people when they get married, the thing they fear is when going into labor, which can cause pain during childbirth. Effective pain management is an important aspect of midwifery care. Pain management includes two types of obstetric intervention pharmacological and non pharmacological interventions. The purpose of this study was to measure the effectiveness and cold compresses on the first stage pain in mothers who gave birth at Puskesmas Jumpandangbaru, Makassar City. This research uses quantitative analytic research with a quasi experimental design study because there is treatment given to groups of mothers who are about to give birth. This research will be carried out in the Jumpadangbaru Community Health Center Work Area from January to August 2020. The population in this study were mothers who gave birth at the Jumpandang Baru Community Health Center in Makassar City within the span of the study by limiting the number of samples to at least 30 respondents using the sampling technique, namely women who happened to be met at the time of this research. The results were processed using SPSS, the data normality test showed that if the data were not normally distributed, the test used was the Wilcoxon test with a sig value for cold warm compresses 0.163 while for back massage the sig value was 0.01 . The conclusion of this study is back massage is more effective when given warm and cold compresses to reduce pain during labor.
\end{abstract}

Key words: labor pain, massage, hot cold compress

\section{ABSTRAK}

Nyeri persalinan dapat menyebabkan penderitaan bagi ibu dan kesehatannya. Hal tersebut dapat berdampak negatif terhadap hubungan ibu dan bayi. Menurut sebuah penelitian, banyak orang ketika melakukan perkawinan hal yang mereka takutkan adalah ketika akan bersalin yang dapat menyebabkan nyeri pada saat bersalin. Penatalaksanaan nyeri yang efektif adalah aspek penting dalam asuhan kebidanan. Penatalaksanaan nyeri meliputi dua tipe dasar intervensi kebidanan yaitu intervensi farmakologi dan non farmakologi. Tujuan Penelitian ini adalah untuk mengetahui perbedaan efektivitas masase dan kompres panas dingin terhadap pengurangan nyeri kala I pada ibu bersalin di Puskesmas Jumpandangbaru, Kota Makassar. Penelitian ini menggunakan jenis penelitian kuantitatif analitik dengan studi desain quasi eksprimen karena ada perlakuan yang diberikan kepada dua kelompok ibu yang akan bersalin. Penelitian ini akan dilaksanakan di Wilayah Kerja Puskesmas Jumpadangbaru pada bulan Januari sampai dengan Bulan Agustus 2020. Populasi dalam penelitian ini adalah ibu yang bersalin di Puskesmas Jumpandang Baru Kota Makassar dalam rentang waktu penelitian dengan membatasi jumlah sampel minimal 30 responden dengan menggunakan teknik pengambilan sampel aksidental sampling, yaitu ibu bersalin yang kebetulan ditemui saat penelitian ini dilaksanakan. Hasil penelitian diolah menggunakan SPSS, uji normalitas data menunjukkan jika data tidak terdistribusi normal sehingga uji yang digunakan adalah uji Wilcoxon dengan nilai sig pada kompres hangat dingin 0,163 sedangkan untuk masase punggung nilai sig 0,01. Kesimpulan penelitian ini adalah Masase Punggung lebih Efektif daripada kompres hangat dingin untuk mengurangi nyeri pada persalinan.

Kata kunci : Nyeri Persalinan, Masase, Kompres Panas Dingin

\section{PENDAHULUAN}

Proses kelahiran identik dengan rasa nyeri yang akan dijalani, dimana sebagian besar persalinan disertai rasa nyeri. Nyeri pada persalinan merupakan proses yang fisiologis. Nyeri menyebabkan frustasi dan putus asa, sehingga beberapa ibu merasa khawatir tidak akan mampu melewati proses persalinan. Sebuah studi terbaru menemukan bahwa $67 \%$ wanita merasa sedikit khawatir, $12 \%$ merasa sangat khawatir dan $23 \%$ sama sekali tidak khawatir tentang nyeri persalinan..

Nyeri persalinan dapat menyebabkan penderitaan bagi ibu dan kesehatannya. Hal tersebut dapat berdampak negatif terhadap hubungan ibu dan bayi. Menurut sebuah penelitian menunjukkan bahwa banyak orang ketika melakukan perkawinan hal yang mereka takutkan adalah ketika akan bersalin yang dapat menyebabkan nyeri pada saat bersalin. Dalam penelitian lain yang dilakukan di Amerika Serikat mengungkapkan bahwa sebanyak $84 \%$ ibu yang akan bersalin memilih untuk menggunakan tehnik non-farmakologi untuk mengurangi rasa nyeri persalinan (Cepeda, Db, Lau, \& Alvarez, 2006)

Penatalaksanaan nyeri yang efektif adalah aspek penting dalam asuhan kebidanan. Penatalaksanaan nyeri meliputi dua tipe dasar intervensi 
kebidanan, intervensi farmakologi dan non farmakologi. Penatalaksanaan nyeri secara farmakologi melibatkan penggunaan obat. Penatalaksanaan nyeri secara non farmakologi, meliputi stimulasi kutaneus (Maryunani, 2010).

Stimulasi kutaneus atau terapi berbasis suhu ini berupa kompres panas dan kompres dingin. Kompres pada tubuh bertujuan untuk meningkatkan perbaikan dan pemulihan jaringan. Efek panas dapat meredakan nyeri dengan meningkatkan relaksasi otot sedangkan efek dingin dapat meredakan nyeri dengan memperlambat kecepatan konduksi saraf dan menghambat impuls saraf (Sjamsuhidajat \& Jong, 2013)

Pemijatan secara lembut akan membantu ibu merasa lebih segar, rileks dan nyaman selama persalinan. Sebuah penelitian menyebutkan ibu yang dipijat 20 menit setiap jam selama tahapan persalinan akan lebih bebas dari rasa sakit. Hal yang terjadi karena pijat merangsang tubuh melepas senyawa endorfin juga dapat menciptakan perasaan nyaman dan enak (Pastuty \& Rosyanti, 2010).

Nyeri persalinan adalah kondisi yang normal terjadi pada kala I persalinan. Nyeri ini akan semakin kuat dan sering seiring dengan bertambahnya pembukaan. Kondisi nyeri yang hebat pada kala I persalinan memungkinkan para ibu memilih cara persalinan yang mudah dan cepat tanpa harus merasakan nyeri. Hartiningsih (2011) dalam penelitiannya menyebutkan bahwa tingginya angka section caesarea karena ibu cenderung tidak sanggup menerima pengalaman nyeri yang dirasakannya. Berdasarkan hal tersebut penulis tertarik untuk melakukan penelitian dengan judul "Perbedaan Efektivitas Masase dan Kompres Kompres Panas Dingin terhadap Pengurangan Nyeri Kala I Pada Ibu Bersalin Di Puskesmas Jumpandangbaru, Kota Makassar"

Berdasarkan latar belakang diatas, maka dapat dirumuskan masalah penelitian apakah ada Perbedaan Efektivitas Masase dan Kompres Kompres Panas Dingin terhadap Pengurangan Nyeri Kala I Pada Ibu Bersalin Di Puskesmas Jumpandangbaru, Kota Makassar. Tujuan Penelitian ini adalah untuk mengetahui perbedaan efektivitas masase dan kompres kompres panas dingin terhadap pengurangan nyeri kala I pada ibu bersalin
Di Puskesmas Jumpandangbaru, Kota Makassar

\section{METODE}

\section{Desain, tempat dan waktu}

Penelitian ini menggunakan jenis penelitian kuantitatif analitik dengan studi desain quasi eksprimen karena ada perlakuan yang diberikan kepada dua kelompok ibu yang akan bersalin (Sopiyuddin Dahlan, 2014). Penelitian ini membandingkan efektivitas pengurangan nyeri yang dirasakan oleh ibu bersalin dengan menggunakan teknik masase dengan kompres hangat dan kompres dingin

Penelitian ini akan dilaksanakan di Wilayah Kerja Puskesmas Jumpandang baru pada bulan Maret sampai dengan Bulan September 2020.

\section{Populasi dan Subjek Penelitian}

Populasi dalam penelitian ini adalah ibu yang bersalin di Puskesmas Jumpandang Baru Makassar dalam rentang waktu penelitian dengan membatasi jumlah sampel minimal 30 responden dengan menggunakan teknik pengambilan sampel aksidental sampling, yaitu ibu bersalin yang kebetulan ditemui saat penelitian ini dilaksanakan.

\section{Jenis dan Cara Pengumpulan Data.}

Data yang digunakan dalam penelitian ini adalah data primer, ibu bersalin fase aktif pembukaan $7-10 \mathrm{~cm}$ dibagi menjadi 2 kelompok masing-masing berjumlah 15 orang. Kedua kelompok diukur dulu tingkat nyeri yang dirasakan dengan menggunakan lembar observasi yang berisi skala pengukuran nyeri dengan metode Faces Pain Rating Scale (FPRC). Setelah diukur maka masing-masing kelompok diberikan intervensi. Kelompok pertama diberikan masase, sedangkan kelompok kedua diberikan kompres hangat dan kompres dingin. Kedua teknik ini dilakukan setiap kali ada kontraksi untuk menilai apakah ada penurunan tingkat nyeri yang dirasakan dengan menggunakan lembar observasi.

\section{Pengolahan dan analisis data}

Analisis data dilakukan dengan mengumpulkan lembar observasi yang telah diperoleh pada dua kelompok ibu bersalin. Lembar observasi sebelum intervensi dan setelah intervensi dibandingkan. Hasilnya diberi kode, kemudian dilakukan analisis 
univariat dalam table distribusi frekuensi dan analisis bivariate dengan menggunakan uji t jika data terdisribusi normal atau uji Wilcoxon jika data terdistribusi tidak normal yaitu untuk menguji rata-rata dua kelompok sampel yang representative. Perhitungan dilakukan dengan menggunakan SPSS dengan tingkat kemaknaan $\alpha=0,05$ (Stang, 2014).

\section{HASIL}

\section{Analisis Univariat}

1. Umur

Berdasarkan tabel 1 diperoleh data bahwa responden yang berumur < 20 dan > 35 Tahun sebanyak 13 responden $(43.3 \%)$ dan responden yang berumur $20-35$ tahun sebanyak 17 responden (47.7\%).

2. Pendidikan

\section{Berdasarkan tabel 2 diperoleh} data bahwa responden yang berpendidikan Rendah sebanyak 8 Responden (16\%), responden yang berpendidikan SMA sebanyak 20 orang $(66.7 \%)$ dan responden yang berpendidikan Sarjana sebanyak 2 Responden (6.7\%).

3. Pekerjaan

Berdasarkan tabel 3 diperoleh data bahwa responden yang bekerja sebagai IRT sebanyak 6 Responden $(20 \%)$, responden yang bekerja sebagai wiraswasta sebanyak 12 responden $(40 \%)$ dan yang bekerja sebagai PNS sebanyak 20 responden (40\%)

4. Pretest Kompres Hangat Dingin

Berdasarkan tabel 4 diperoleh data bahwa responden dengan intensitas nyeri ringan tidak ada, nyeri sedang 7 responden $(46.7 \%)$, nyeri berat sebanyak 7 Responden (46.7\%) dan nyeri sangat berat sebanyak 1 responden (6.7\%).

5. Posttest Kompres Hangat Dingin

Berdasarkan tabel 5 diperoleh data bahwa responden dengan intensitas nyeri ringan tidak ada, nyeri sedang 8 responden $(53.3 \%)$, nyeri berat sebanyak 7 Responden (46.7\%) dan nyeri sangat berat tidak ada.

6. Pretest Masase Punggung

Berdasarkan tabel 6 diperoleh data bahwa responden dengan intensitas nyeri ringan tidak ada, nyeri sedang 3 responden $(20.0 \%)$, nyeri berat sebanyak 10 Responden (66.7\%) dan nyeri sangat berat sebanyak 2 responden (13.3\%).

7. Posttest Masase Punggung

Berdasarkan tabel 7 diperoleh data bahwa responden dengan intensitas nyeri ringan sebanyak 1 responden $(6.7 \%)$, nyeri sedang 10 responden $(66.7 \%)$, nyeri berat sebanyak 4 Responden (13.3\%) dan nyeri sangat berat tidak ada.

\section{Analisis Bivariat}

1. Uji Normalitas Data

Uji normalitas data yaitu hasil uji normalitas sebelum dan sesudah diberikannya intervensi kompres hangat dan masase punggung untuk mengurangi rasa nyeri persalinan Kala I dengan pembukaan 7-9 cm

Pada uji normalitas tabel 8 pada kolmogorof-smirnoh dan shapiro wilk terdapat 2 data dengan nilai Sig $(p<0,05)$ dengan demikian data tidak distribusi normal. Berdasarkan data yang tidak berdistribusi normal diatas maka langkah berikutnya adalah melakukan uji statistik dengan menggunakan Uji Willcoxon yang merupakan uji statistik Nonparametrik.

2. Tes statistik perbedaan instensitas nyeri dengan kompres hangat dingin dan masase

Tabel 9 menunjukkan bahwa Asymp. Sig dari kompres hangat dingin sebesar $p=0,163$, dan Asymp. Sig dari masase sebesar $p=0,01$. Hal ini menunjukkan bahwa salah satu dari intervensi berikut memiliki beda yang signifikan yaitu intervensi masase punggung dengan nilai $p<0,05$ yang berarti memiliki beda yang signifikan dengan intervensi kompres hangat dingin.

\section{PEMBAHASAN}

Hasil penelitian yang diperoleh menunjukkan nyeri persalinan yang dirasakan oleh ibi sebelum dan sesudah kompres hangat dingin perbedaanya tidak signifikan denngan nilai sig 0,163 sedangkan untuk intervensi masase punggung terdapat perbedaan yang signifikan sebelum dan sesudah intervensi dengan nilai sig 0,01 .

Penelitian ini sejalan dengan penelitian yang dilakukan oleh (Ersila, Prafitri, \& Zuhana, 2019) dengan Hasil terdapat perbedaan massage effelurage dan 
kompres dingin terhadap nyeri persalinan dengan nilai p 0,001 $(<0,05)$ sehingga dapat disimpulkan massage effleurage lebih efektif untuk menurunkan nyeri persalinan.

Berbeda dengan penelitian yang dilakukan oleh (Rosalinda, Firda Fibrila, \& Sumiyati, 2011) dengan hasil didapat proporsi penurunan nyeri pada teknik kompres hangat yaitu 27 pasien $(90 \%)$ dan proporsi penurunan nyeri pada teknik masase yaitu 24 pasien (80\%). Hasil uji statistik diketahui perbedaan teknik kompres hangat dan teknik masase dalam mengurangi nyeri persalinan kala I didapat thitung $>$ t-tabel yaitu 3,05>2,00.

Penelitian yang dilakukan oleh (Rahman, Handayani, \& Mallongi, 2017) juga menjelaskan bahwa Terdapat penurunan skala nyeri persalinan sebelum dan setelah terapi pada kelompok intervensi. Sebelum terapi, skala nyeri terendah adalah 6 dan skala nyeri tertinggi adalah 8 dengan rata- rata skala nyeri adalah 7,00. Sedangkan setelah terapi, skala nyeri terendah adalah 3 dan skala nyeri tertinggi adalah 6 dengan rata-rata skala nyeri adalah 4,14. Ada pengaruh kompres hangat dan massage effleurage terhadap penurunan nyeri persalinan pada primipara selama kala satu persalinan setelah dilakukan intervensi dengan nilai $p=0,000$

Nyeri merupakan rangsangan tidak enak dapat menimbulkan rasa takut dan khawatir. Dalam persalinan, nyeri yang dirasakan dapat menimbulkan rasa takut dan stress yang menyebabkan pengurangan aliran darah dari ibu ke janin, akibatnya dapat terjadi hipoksi janin sampai dengan asfiksia (Andarmayo, 2013)

Masase adalah tindakan penekanan oleh tangan pada jaringan lunak, biasanya pada otot tendon atau ligament, tanpa menyebabkan pergeseran atau perubahan posisi sendi guna menurunkan nyeri, menghasilkan relaksasi, atau meningkatkan sirkulasi. Tindakan masase ini akan menutup pintu gerbang jalur nyeri. Dengan masase juga akan menimbulkan efek psikososial yang baik untuk ibu bersalin. Dianjurkan agar masaseselama persalinan harus bersifat terus menerus. Hal tersebut harus dilakukan karena terdapat kecendrungan rasa nyeri akan meningkat jika pemijatan dihentikan, hal ini di sebabkan system saraf yang sudah terbiasa dengan stimulus tersebut dan organ indera terbiasa merespon nyeri tersebut (Armawan E, 2013)
Prinsip penggunaan aplikasi kompres panas ini adalah meningkatkan aliran darah sehingga mengurangi spasme otot karena iskemia. Sedangkan kompres dingin menggunakan prinsip berkurangnya sensitivitas kulit dan otot superfisial dengan dingin yang berlebihan (Armawan E, 2013)

Berdasarkan hasil penelitian ini Penurunan nyeri persalinan dengan dilakukan masase punggung lebih efektif dengan hasil sebelum masase responden yang mengalami nyeri berat mencapai $66,7 \%$ setelah dilakukan masase punggung nyeri berat hanya mencapai $13,3 \%$. Sedangkan nyeri persalinan pada kelompok yang dilakukan kompres hangat dingi sebelum intervensi yang mengalami nyeri berat mencapai $46,7 \%$ setelah intervensi keadaan ibu yang mengalami nyeri persalinan cenderung tetap.

\section{KESIMPULAN}

Hasil penelitian ini menunjukkan bahwa Masase Punggung lebih Efektif daripada kompres hangat dan dingin dengan nilai sig 0,01 ..

\section{SARAN}

1. Untuk Puskesmas

Senantiasa memberikan

kenyamanan kepada pasien dengan meberikan asuhan sayang ibu salah satunya dengan membantu proses persalinan dengan mengurangi nyeri yang dirasakan.

2. Untuk Ibu Bersalin

Mampu beradaptasi dengan nyeri yang dirasakan.

3. Untuk Peneliti Selanjutnya.

Sebagai acuan bagi peneliti selanjutnya untuk dijadikan pembanding atau data awal.

\section{UCAPAN TERIMAKASIH}

Kepada yang terhormat :

1. Kementrian Ristek dan Teknologi/Badan Riset dan Inovasi nasional yang telah membiayai penelitian ini melalui Hibah Eksternal Skim Penelitian Dosen Pemula (PDP).

2. Ketua STIKES Nani Hasanuddin Makassar Bapak Sri Darmawan yang memberikan dukungan motivasi dan materil.

3. Kepala P3M STIKES Nani Hasanuddin Makassar, Ibu Suarnianti yang selalu memberikan motivasi kepada dosen 
untuk produktif menghasilkan penelitian dan pengabdian pada masyarakat

4. Kepala Puskemas Jumpandang Baru yang telah memberi izin melaksanakan penelitian di Puskesmas Bangkala

5. Responden yang bersedia bekerjasama memberikan data dan informasi sehingga penelitian ini dapat terlaksana.

\section{DAFTAR PUSTAKA}

Cepeda, Db, C., Lau, J., \& Alvarez, H. (2006). Music for pain relief ( Review), (2). Retrieved from https://www.cirmmt.org/activities/work shops/research/musicpain/images/musicforpainreliefofcochr ane-rev-2006

Ersila, W., Prafitri, L. D., \& Zuhana, N. (2019). Perbedaan Efektivitas Massage Effleurage Dan Kompres Jurnal SIKLUS Volume 08 Nomor 02 , Juni 2019, 08, 107-115.

Maryunani. (2010). Nyeri Persalinan. Jakarta: Salemba Medika.

Pastuty, \& Rosyanti. (2010). Buku Saku Asuhan Kebidanan lbu Bersalin.
Jakarta: EGC.

Rahman, S. A., Handayani, A., \& Mallongi, A. (2017). Penurunan Nyeri Persalinan Dengan Kompres Hangat Dan Massage Effleurage Decrease Of Labor Pain With Warm Compress And Effleurage Massage, 13(2), 147-151.

Rosalinda, D., Firda Fibrila, \& Sumiyati. (2011). Perbedaan Teknik Kompres Hangat dan Teknik Masase Untuk Mengurangi Nyeri Persalinan Kala I 71, IV(1), 71-77.

Sjamsuhidajat, \& Jong, D. (2013). Buku Ajar IImu Bedah (3rd ed.). Jakarta: EGC.

Sopiyuddin Dahlan. (2014). Pintu Gerbang memahami statistic, metodologi dan epidemologi. Jakarta: Sagung Seto.

Stang. (2014). Cara Praktis Penentuan uji statistic dalam penelitian kesehatan dan kedokteran. Jakarta: Mitra Wacana Media. 
Tabel 1.

Distribusi Frekuensi berdasarkan umur di Puskesmas Jumpandang Baru Kota Makassar

\begin{tabular}{lcc}
\hline \multicolumn{1}{c}{ Umur } & $\mathbf{N}$ & $\%$ \\
\hline $\begin{array}{l}\text { <20 dan } \\
\text { 35 Tahun }\end{array}$ & 13 & 43.3 \\
\hline $\begin{array}{l}20-35 \\
\text { Tahun }\end{array}$ & 17 & 47.7 \\
\hline Total & 30 & 100 \\
\hline
\end{tabular}

Tabel 2.

Distribusi Frekuensi Responden

Berdasarkan Pendidikan di Puskesmas Jumpandang Baru Kota Makassar

\begin{tabular}{lcc}
\hline Pendidikan & $\mathbf{N}$ & $\%$ \\
\hline Rendah & 8 & 26.7 \\
\hline Menengah & 20 & 66.7 \\
\hline Tinggi & 2 & 6.7 \\
\hline Total & $\mathbf{3 0}$ & $\mathbf{1 0 0}$ \\
\hline
\end{tabular}

Tabel 3.

Distribusi Frekuensi Responden Berdasarkan Pekerjaan di Puskesmas Jumpandang Baru Kota Makassar

\begin{tabular}{lcc}
\hline \multicolumn{1}{c}{ Pekerjaan } & $\mathbf{N}$ & $\%$ \\
\hline IRT & 6 & 20 \\
\hline WIRASWASTA & 12 & 40 \\
\hline PNS & 12 & 40 \\
\hline Total & $\mathbf{3 0}$ & $\mathbf{1 0 0}$ \\
\hline
\end{tabular}

Tabel 4.

Distribusi Frekuensi Intensitas Nyeri Responden sebelum kompres hangat dingin di Puskesmas Jumpandang Baru Kota Makassar

\begin{tabular}{llc}
\hline $\begin{array}{c}\text { Intensitas } \\
\text { Nyeri }\end{array}$ & $\mathbf{N}$ & $\%$ \\
\hline Ringan & 0 & 0 \\
\hline Sedang & 7 & 46.7 \\
\hline Berat & 7 & 46.7 \\
\hline Sangat & 1 & 6.7 \\
Berat & & 100 \\
\hline Total & 30 & \\
\hline
\end{tabular}


Tabel 5.

Distribusi Frekuensi Intensitas Nyeri Responden setelah Kompres Hangat Dingin di Puskesmas Jumpandang Baru Kota Makassar

\begin{tabular}{lcc}
\hline $\begin{array}{l}\text { Intensitas } \\
\text { Nyeri }\end{array}$ & $\mathbf{N}$ & $\%$ \\
\hline Ringan & 0 & 0 \\
\hline Sedang & 8 & 53.3 \\
\hline Berat & 7 & 46.7 \\
\hline $\begin{array}{l}\text { Sangat } \\
\text { Berat }\end{array}$ & 0 & 0 \\
\hline Total & 30 & 100 \\
\hline
\end{tabular}

Tabel 6.

Distribusi Frekuensi Intensitas Nyeri Responden sebelum Masase di Puskesmas Jumpandang Baru Kota Makassar

\begin{tabular}{lcc}
\hline $\begin{array}{c}\text { Intensitas } \\
\text { Nyeri }\end{array}$ & $\mathbf{N}$ & $\%$ \\
\hline Ringan & 0 & 0 \\
\hline Sedang & 3 & 20.0 \\
\hline Berat & 10 & 66.7 \\
\hline $\begin{array}{l}\text { Sangat } \\
\text { Berat }\end{array}$ & 2 & 13.3 \\
\hline Total & 30 & 100 \\
\hline
\end{tabular}

Tabel 7.

Distribusi Frekuensi Intensitas Nyeri Responden setelah Masase di Puskesmas Jumpandang Baru Kota Makassar

\begin{tabular}{lcc}
\hline $\begin{array}{l}\text { Intensitas } \\
\text { Nyeri }\end{array}$ & $\mathbf{N}$ & $\%$ \\
\hline Ringan & 1 & 6.7 \\
\hline Sedang & 10 & 66.7 \\
\hline Berat & 4 & 13.3 \\
\hline $\begin{array}{l}\text { Sangat } \\
\text { Berat }\end{array}$ & 0 & 0 \\
\hline Total & 30 & 100 \\
\hline
\end{tabular}


Tabel 8.

Hasil uji normalitas data

Tests of Normality

\begin{tabular}{llccccccc}
\hline & & \multicolumn{3}{c}{ Kolmogorov-Smirnov $^{\mathrm{y}}$} & \multicolumn{3}{c}{ Shapiro-Wilk } \\
\cline { 2 - 8 } & Hasil & Statistic & $\mathrm{df}$ & Sig. & Statistic & $\mathrm{df}$ & Sig. \\
\hline Hasil & Pre test Kompres & .205 & 15 & .088 & .909 & 15 & .130 \\
$\begin{array}{l}\text { observasi } \\
\text { intensitas }\end{array}$ & Post test & & & & & & & \\
nyeri & Kompres & .212 & 15 & .068 & .834 & 15 & .010 \\
& Pretest masase & .193 & 15 & .136 & .945 & 15 & .446 \\
& posttest masase & .238 & 15 & .022 & .865 & 15 & .029 \\
\hline
\end{tabular}

a. Lilliefors Significance Correction

b. This is a lower bound of the true significance.

Tabel 9.

Hasil Uji Wilcoxon

Test Statistics ${ }^{b}$

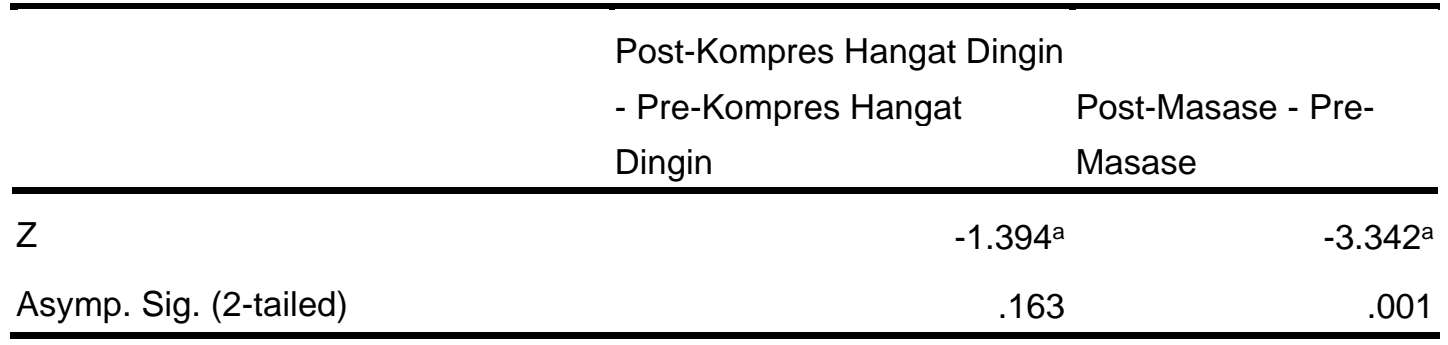

a. Based on positive ranks.

b. Wilcoxon Signed Ranks Test 